"Mircea cel Batran" Naval Academy Scientific Bulletin, Volume XIX - 2016 - Issue 2 The journal is indexed in: PROQUEST / DOAJ I Crossref / EBSCOhost / INDEX COPERNICUS I DRJI / OAJI I JOURNAL INDEX I I2OR / SCIENCE LIBRARY INDEX / Google Scholar / Academic Keys/ ROAD Open Access I Academic Resources / Scientific Indexing Services / SCIPIO / JIFACTOR

\title{
A STUDY REGARDING SHOCK WAVE PROPAGATION WHEN AN UNDERWATER EXPLOSION OCCURS
}

\author{
Gheorghe ICHIMOAEI ${ }^{1}$ \\ Cătălin CLINCI ${ }^{2}$ \\ Octavian TĂRĂBUŢA $\breve{A}^{3}$ \\ Beazit ALI ${ }^{4}$
}

${ }^{1}$ Lecturer PhD., "Mircea cel Batran" Naval Academy

2Lecturer PhD., "Mircea cel Batran" Naval Academy

${ }^{3}$ Assistant professor PhD., "Mircea cel Batran" Naval Academy

${ }^{41}$ Professor Ph.D.Eng.,Marine Engineering and Naval Weapons Department, "Mircea cel Batan" Naval

Academy, Constanţa, Romania

\begin{abstract}
In this paper we briefly studied the effect of underwater explosion on ship hull. For a qualitative analyze, we studied the effect of underwater explosion for two cases: for a compact explosive charge and for a multiple explosive charge.
\end{abstract}

Keywords: shock wave, underwater explosion, multiple explosive charge

Marine mines could be divided in two categories, regarding the ignition way: contact mines and less contact mines. Contact mines will explode when the mine will be hit by the ship hull. In this case, the effects of the explosion will be:

- Direct action of the shock wave on the ship's hull;

- Action of the shock wave induced on the ship stiffness structure.

Less contact mines will explode when the mine will "feel" some variation of magnetic field or will "heard" noises produces by ship engines and propellers. In this case, the effects of the explosion will be:

- gas bubble generated by explosive charge decomposition;

- gas bubble generated at explosive charge detonation.

In correlation with the distance between mine and ship, we can made two analyses:

- the explosion occurs when this distance is equal with maximum radius of gas bubble or less than this radius;

- the explosion occurs out of gas bubble radius.

In the first case, explosion effect will be given by the peak pressure of shock wave, by hydraulic shock generated when the gas bubble will rebound and by the direct action of gas bubble on ships hull.

In the second case, explosion effect will be given by the peak pressure of shock wave and, eventually by the pneumatic shock produced by water movement when the gas bubble will rebound. If the explosion will be under the ship, the explosion effect will be increased by the gas bubble movement, when the bubble is going to surface.
Shock wave generated by an underwater explosion could be describes as a peak pressure which is decreasing in time. The pressure-time curve could be represented as:

$$
P(t)=P_{m} e^{\frac{t_{a}-t}{\theta}}
$$

where:

$\mathrm{Pm}$ - peak pressure of shock wave,

$\theta$ - time constant,

$t_{a}$ - time needed by shock wave to reach the ship hull, given by:

$$
t_{a}=\frac{r}{c}
$$

The shock wave propagation is represented in figure 1 , at the moment of time $\mathrm{t}$ :

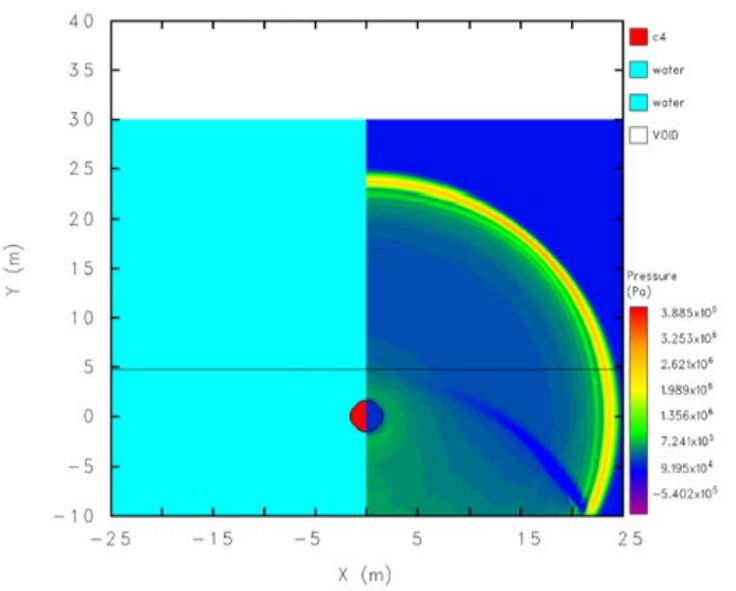

Figure 1 Pressure in the underwater explosion shock wave front [5]

Agreeing with [10], parameters $\mathrm{P}_{\mathrm{m}}$ and $\theta$ are given by: 
"Mircea cel Batran" Naval Academy Scientific Bulletin, Volume XIX - 2016 - Issue 2 The journal is indexed in: PROQUEST I DOAJ / Crossref / EBSCOhost / INDEX COPERNICUS / DRJI / OAJI I JOURNAL INDEX I I2OR / SCIENCE LIBRARY INDEX / Google Scholar / Academic Keys/ ROAD Open Access I Academic Resources / Scientific Indexing Services / SCIPIO / JIFACTOR

$$
\begin{aligned}
& P_{m}=53,1 *\left(\frac{w^{1 / 3}}{r}\right)^{1,13}[\mathrm{MPa}] \\
& \theta=9,2 * 10^{-3} * w^{1 / 3}\left(\frac{w^{1 / 3}}{r}\right)^{0,18}[\mathrm{sec}]
\end{aligned}
$$

where:

- $\quad$ w - weight of explosive charge $[\mathrm{kg}]$

- $\quad r$ - distance from explosion position to the observation point;

- $\quad$ c - speed of sound in water, as:

- $\quad$ - fresh water: $c=(1498 \div 1523) \mathrm{m} / \mathrm{s}$

- $\quad$ - sea water: $\mathrm{c}=(1535 \div 1770) \mathrm{m} / \mathrm{s}$.

Usually: $c=1550 \mathrm{~m} / \mathrm{s}$.

In order to study the shock wave pressure, we chose three less contact mines, placed on the sea bottom at 35 meters depth (figure 2). The explosives charges of mines will have weight 50 , 100 and 300 kilos.

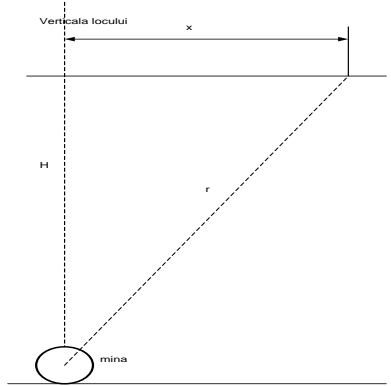

Figure 2 Mine position

In figure 2 we made the following notations:

- $\quad \mathrm{H}$ - water depth;

- $\quad x$ - lateral distance (place where the ship will be when mine explosion occurs);

- $\quad r$ - distance from mine to ship hull

We computed the pressures which will interact with ship hull, depending on the relative position of ship hull with plumb mine. Pressure distribution on the shock wave front could be represented as in figure 3.

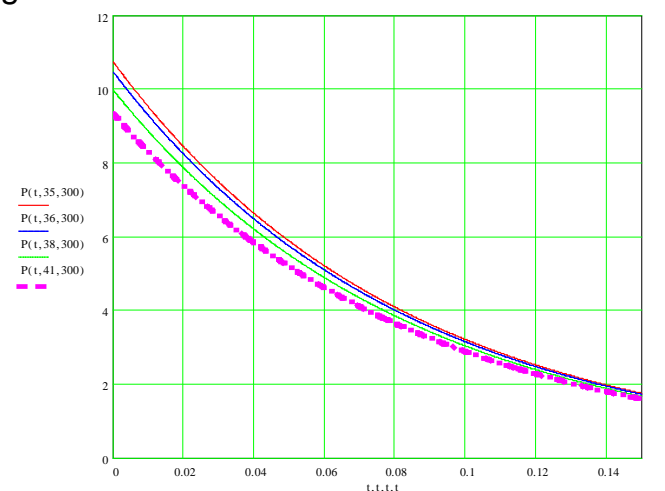

Figure 3 Pressure distribution on the shock wave front computed for a mine placed at 35 meters depth

Analyzing all the situations described before, we can write the results, as you can see in table 1.
Table 1. Comparative values of shock wave pressure

\begin{tabular}{|c|c|c|c|}
\hline $\begin{array}{c}x \\
{[\mathrm{~m}]}\end{array}$ & \multicolumn{3}{|c|}{$\mathrm{P}[\mathrm{MPa}]$} \\
\cline { 2 - 4 } & $\mathrm{w}=50 \mathrm{~kg}$ & $\mathrm{w}=100 \mathrm{~kg}$ & $\mathrm{w}=300 \mathrm{~kg}$ \\
\hline 5 & 6,5 & 7,8 & 10,7 \\
\hline 10 & 6,3 & 7,6 & 10,5 \\
\hline 15 & 6,1 & 7,2 & 10 \\
\hline 20 & 5,85 & 6,9 & 9,3 \\
\hline
\end{tabular}

\begin{tabular}{|c|c|c|}
\hline \multirow{2}{*}{$\begin{array}{c}x \\
{[\mathrm{~m}]}\end{array}$} & \multicolumn{2}{|c|}{$\Delta \mathrm{P}[\%]$} \\
\cline { 2 - 3 } & $\Delta \mathrm{w}=200 \%$ & $\Delta \mathrm{w}=600 \%$ \\
\hline 5 & 20 & 64,6 \\
\hline 10 & 20,6 & 66,6 \\
\hline 15 & 18,1 & 63,9 \\
\hline 20 & 17,9 & 58,9 \\
\hline
\end{tabular}

Based on result from Table 1, we can make the following statements:

- if the weight of explosive charge will be doubled the peak pressure of shock wave increase by $20 \%$;

- if the weight of explosive charge will be increased by six times the peak pressure of shock wave increase by $60 \%$;

- We can draw the following conclusion: regarding the weight of explosive charge, marine mines are oversized. For this reason, it will be interesting to study the effects of explosion produced by a mine with multiple charge. In this case, the weight of explosive charge ought to be at least equal with the weight of explosive charges of mines analyzed before.

Mine with multiple charges consist in two bodies filled with explosive, which are placed, one on the bottom of the sea and the other in moored at a certain depth. Mine with multiple charges could be represented as in figure 4.

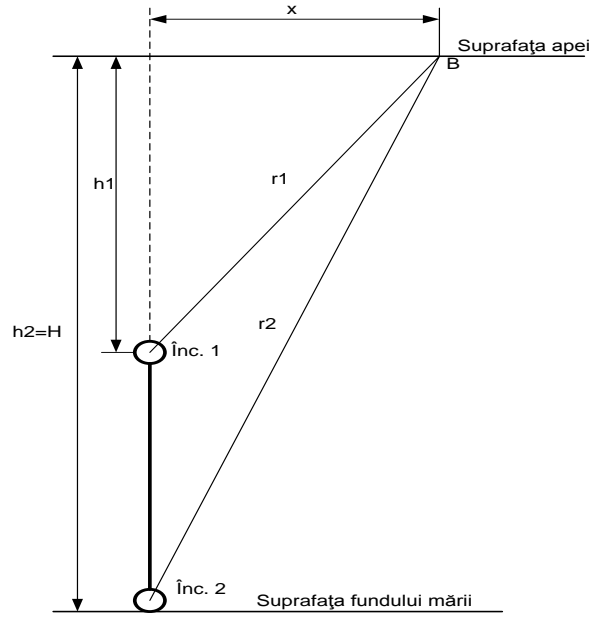

Figure 4 Mine with multiple charges

One of the characteristics for mines with multiple charges, is that the both explosive charges 
"Mircea cel Batran" Naval Academy Scientific Bulletin, Volume XIX - 2016 - Issue 2 The journal is indexed in: PROQUEST I DOAJ / Crossref / EBSCOhost / INDEX COPERNICUS / DRJI / OAJI I JOURNAL INDEX I I2OR / SCIENCE LIBRARY INDEX / Google Scholar / Academic Keys/ ROAD Open Access I Academic Resources / Scientific Indexing Services / SCIPIO / JIFACTOR

detonates at the same time. In point $B$ is recorded the pressure for shock wave generated by charge 1 , and after a short time this pressure will be overlapped by pressure of shock wave produced by charge 2 .

As an example, we will take into consideration a mine with two charges, placed at $20 \mathrm{~m}$ depth, respectively at $35 \mathrm{~m}$ depth. In Figure 5 , you can see pressure variation in point $B$, depending on value of lateral distance $x$.

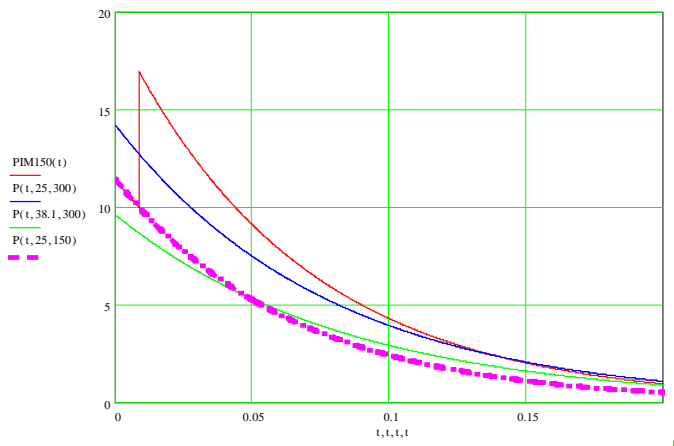

Figure 5 Pressure in shock wave front produced when a mine with multiple charges explodes

We computed the pressure values for the following situations:

- Mine is with multiple charges, the weight of both explosives charges is half of the explosive charge weight of initial mine. Charges are placed at $20 \mathrm{~m}$ depth, respectively at $35 \mathrm{~m}$ depth;

- Mine has one explosive charge placed at $20 \mathrm{~m}$ Table 2. Pressure values in shock wave

\begin{tabular}{|c|c|c|c|c|c|}
\hline \multicolumn{2}{|c|}{$\mathrm{w}[\mathrm{kg}]$} & \multicolumn{4}{|c|}{$\mathrm{x}[\mathrm{m}]$} \\
\hline \multirow[b]{2}{*}{$\begin{array}{l}E \\
\stackrel{N}{ } \\
I 1 \\
\vec{E}\end{array}$} & \multirow[b]{2}{*}{$\begin{array}{l}E \\
L \\
m \\
\| \\
\stackrel{N}{N}\end{array}$} & \multicolumn{2}{|c|}{5} & \multicolumn{2}{|c|}{10} \\
\hline & & $\begin{array}{l}\sum_{\alpha}^{\sigma} \\
\sum^{\alpha}\end{array}$ & $\frac{\overline{0}}{8}$ & $\begin{array}{l}\bar{\sigma} \\
\sum_{0}^{\bar{\alpha}}\end{array}$ & $\frac{2}{2}$ \\
\hline 50 & 50 & 13,1 & 100 & 12,5 & 100 \\
\hline 100 & 0 & 12 & 92 & 11 & 88 \\
\hline 0 & 100 & 7,5 & 57 & 7 & 56 \\
\hline 150 & 150 & & & & \\
\hline 300 & 0 & & & & \\
\hline & 300 & & & & \\
\hline
\end{tabular}
depth;

- Mine has one explosive charge placed at $35 \mathrm{~m}$ depth.

The result of computations are in Table 2.

\section{CONCLUSIONS}

Based on values which are written on Table 2, we can draw the following conclusion:

The maximum pressure of the shock wave front resulting from an explosion of a compacted explosive is lower by up to $50 \%$ than the maximum pressure given by the explosion of the same amount of explosive equally divided into two charges placed at a distance from one to another;

If the lateral distance will increase, the explosive charge efficiency decrease;

The same effect on the ship hull is achieved using a smaller amount of explosive, divided into several charges placed at different depths.

\section{BIBLIOGRAPHY}

[1] Bărbărie, Şt., Bazele proiectării minelor marine şi fluviale, Editura Academiei Navale „Mircea Cel Bătrân”, Constanţa, 1994.

[2] Cole, R., Underwater explosion, Princeton University Press, 1948.

[3] Goga, D.A., Probleme speciale de detonică, Editura Academiei Tehnice Militare, Bucureşti, 2004.

[4] Goga, D.A., Conception etrealisation d'un générateurd'onde de choc plane par relévement de plaque, Rapport D.E.A. Poitiers, 1997.

[5] Peter T. Dzwilewski, P. T., Fenton, G., Shock Wave/Sound Propagation Modeling Results for Calculating Marine Protected Species Impact Zones During Explosive Removal of Offshore Structures Minerals Management Service Gulf of Mexico OCS Region, New Orleans September 2003

[6] Toma A., Considerations on effects of gas buble on submerged submarin, The 32nd international scientific conference of the military technical academy "MODERN TECHNOLOGIES IN THE 21st CENTURY", ISBN 978-973-640-127-5, pag. 5.1-5.6, Academia Tehnică Militară, Bucureşti, 2007. 
"Mircea cel Batran" Naval Academy Scientific Bulletin, Volume XIX - 2016 - Issue 2 The journal is indexed in: PROQUEST I DOAJ / Crossref / EBSCOhost / INDEX COPERNICUS / DRJI / OAJI I JOURNAL INDEX I I2OR / SCIENCE LIBRARY INDEX / Google Scholar / Academic Keys/ ROAD Open Access I Academic Resources / Scientific Indexing Services / SCIPIO / JIFACTOR

[7] Toma A., Clinci C., The equations governing the response of a submerged submarine to an underwater gas bubble, Scientific Bulletin of Naval Academy Vol. X-2007, pag. 252-258, Published by "Mircea cel Batran" Naval Academy Press, ISSN 1454-864X (Category B/CNCS).

[8] Toma A., Numerical modeling of interaction between underwatwr gas bubble and submerged torpedoes, Scientific Bulletin of Naval Academy Vol. XIV-2011 Issue no. 2, pag. 124-129, Published by "Mircea cel Batran" Naval Academy Press, ISSN 1454-864X

[9] Toma A., The influence of the initial conditions on the evolution of pressure waves, Scientific Bulletin of Naval Academy Vol. XV-2012, Issue no. 2, pag. 143-148, Published by "Mircea cel Batran" Naval Academy Press, ISSN 1454-864X.

[10] Yefim Gitterman, Avi Shapira, Audio-visual and hydroacoustic observations of the Dead Sea calibration experiment, Geophysical Institute of Israel, Noiembrie 1999 